European Journal of Adapted Physical Activity, 7(2), $32-46$

(C) European Federation of Adapted Physical Activity, 2014

\title{
SELF-EFFICACY OF PRE-SERVICE PHYSICAL EDUCATION TEACHER TOWARD TEACHING STUDENTS WITH DISABILITIES IN GENERAL PHYSICAL EDUCATION CLASSES IN SERBIA
}

\author{
Luka Jovanović \\ Faculty of Kinesiology and Rehabilitation Science, Catholic University, Leuven, Belgium \\ Martin Kudláček \\ Faculty of Physical Culture, Palacký University, Olomouc, Czech Republic \\ Martin E. Block \\ Department of Kinesiology, University of Virginia \\ Ivana Djordjević \\ Faculty of Physical Culture, Palacký University, Olomouc, Czech Republic
}

Corresponding author: Luka Jovanović, E-mail: lukajovanovic88@ gmail.com

\begin{abstract}
The aim of this research is to determine the level of self-efficacy among students studying Sport and Physical Education at the three Universities in Serbia, toward teaching students with intellectual disabilities (ID), physical disabilities (PD) or visual impairment (VI) in GPE classes in Serbia. Participants were 120 students (75 males and 45 females) mean age \pm 22.85 at the last year at Faculty of Sport and Physical Education from University of Belgrade (UBG), University of Nis (UNI) and University of Novi Sad (UNS). SituationalspecificSelf-Efficacy and PhysicalEducatorsScale (SE-PETE-D, Block, Hutzler, Barak\&Klavina, 2013) was used to measure the self-efficacy of PE studentsas well additional information about previous courses and experiences had been provided by questionnaire. T-test indicated statistical differences considering gender at the UBG toward teaching students with ID (mean $\mathrm{F}=3.95$ while mean of male responses was $3.50 ; p=0.01$ ) and at the UNI toward teaching students with VI (mean of $\mathrm{F}=4.13, \mathrm{M}=3.47 ; p=0.03$ ). Significant differences have been found among students' level of self-efficacy from three Universities toward teaching students with ID $(F=8.76 ; p=0.00)$ and PD $(F=5.03 ; p=0.01)$ in GPE classes in Serbia.
\end{abstract}

Keywords:selfefficacy of PE students, inclusion in general physical education, students with disabilities, adapted physical education

\section{INTRODUCTION}

While $80 \%$ of children with disabilities who attend public schools are included in general physical education classes in the US (U.S. Government Accountability Office, 2010), the number of children with disabilities that are included in mainstream schools in Serbia is unknown. Inclusion became a worldwide term in last two decades and consists of educating all students, regarding of their ability or disability, together in one educational environment, while meeting the needs of each of these individuals (Kudlacek, 2001). According to resolution of the United Nations (UN) from 2006 all members of UN shall ensure equal education for all children. There are a lot of parameters that have influences on implementation of successful inclusion such as inadequate teacher training and professional development, perceived lack of competence, lack of support, large class sizes, time and administrative demands, as well as low efficacy to teach individuals with disabilities (Konza, 2008). Attitudes and selfefficacy of future physical education teachers' is seen as one of the most important parameters for successful inclusion. This study is focus on the selfefficacy. Self-efficacy is defined by Bandura (1997) as one's "beliefs in one's capabilities to organize and execute the courses of action required to produce given attainments" (p. 3). The purpose of this 
research is to determine the level of self-efficacy among students at the final year of study sport and physical education toward teaching students with disabilities in general physical education classes in Serbia, to determine is there any differences between genders, whether the type of disability will affect their confidence and students from which Universities feel the most confident and who less. Further goal is to investigate the program at the Faculties of Sport and Physical Education regarding the subjects and courses related to adaptive physical education and inclusion. Participants of this study were the last year Bachelor students of Sport and Physical Education, University of Belgrade, University of Nis and University of Novi Sad. The research was conducted using Situational-specific Self-efficacy and Physical Education scale (SEPETE-D). Students answered on a questions related to teaching students with specific disabilities in GPE classes and how much confident they are in implementing and organizing PE classes.

\section{Inclusion}

According to the Convention on the Rights of People with Disabilities and Optional Protocol of United Nations (UN) from 2006, all States Parties of UN shall ensure equal rights for people with disabilities. The purpose of the Convention is "to promote, protect and ensure the full and equal enjoyment of all human rights and fundamental freedoms by all persons with disabilities, and to promote respect for their inherent dignity". Article 24(1) in convention recognizes rights of persons with disabilities on education and says that all States Parties shall ensure inclusive education system for all without discrimination. In realizing this right, Article 24(2), says that States Parties shall ensure: "a) Persons with disabilities are not excluded from the general education system on the basis of disability, and that children with disabilities are not excluded from free and compulsory primary education, or from secondary education, on the basis of disability; b) Persons with disabilities can access an inclusive, quality and free primary education and secondary on an equal basis with others in the communities in which they live; c) Reasonable accommodation of the individual's requirements is provided; d) Persons with disabilities receive the support required, within the general education system, to facilitate their effective education; e) Effective individualized support measures are provided in environments that maximize academic and social development, consistent with the goal of full inclusion", (United Nations, 2006).

Even the inclusive education has been increasing in last few years in Europe, the inclusive education system in Serbia doesn't implement in the way it should (Pantic, Cloos, \& Macura, 2012). Inclusion is the term which is seen as a service that will provide that all children are educated within the same environment in general education regardless of their abilities or disabilities (Block, 2007) is seen as a service, not a placement (Block, 2003). O'Brien, Kudlacek and Howe (2009) in their review of literature regarding inclusion students with disabilities in physical education examined the research from the year 2000 to 2008, conducted that there is a lack of research which is directly associated with physical education. Inclusion in PE can effectively work for the child with disabilities (Block \& Obrusnikova, 2007; Goodwin \& Watkinson, 2000) without having negative influence on peers without disabilities (Obrusnikova, Block, \& Valkova, 2003). Appropriate inclusion can produce benefits for all students (Lieberman, Alisa, \& Nicole, 2004), provide the same possibilities and opportunities to participate with peers (Mrug \& Wallander, 2002) and change the attitudes of students without disabilities toward their peers with disabilities (Salisbury, Gallucci, Palombaro, \& Peck, 1995). According to Downing (2002); Snell and Eichner (1989) and Stainback and Stainback (1990), student with disabilities in inclusive settings learn to be themselves, have opportunity to learn appropriate social skills, being with peers without disabilities, being include in activities with other students, making a friendships, trust and understanding among each other. With proper guidance students without disabilities learn to respect other individuals and gain empathy, while from perspective of special education teachers and adapted physical education teachers, inclusive environment is more effective than self-contained environment (Downing, 2002; Snell \& Eichner, 1989; Stainback \& Stainback, 1990). Many barriers have been noted in the past as a reason for unsuccessful inclusion such as inadequate teacher training and professional development, perceived lack of competence, lack of support, large class sizes, time and administrative demands, as well as low efficacy to teach individuals with disabilities (Konza, 2008).

In recent years vital part for implementing successful inclusion is teacher's attitudes and teacher's self-efficacy. While teachers' attitudes 
toward teaching students with disabilities in general physical education classes are well documented in the past (Ammah \& Hodge, 2005; Block \& Rizzo, 1995; Hodge et al., 2009; Hardin, 2005; Hutzler, 2003; Kozub \& Lienert, 2003, Martin \& Kudlacek, 2010; Meegan \& MacPhail, 2006), there is an obvious lack of research in regard to self-efficacy of physical education teachers toward teaching students with disabilities (Block et. al., 2013).

Attitudes of Pre-Service PE teachers' toward
inclusion

This study is focus on the self-efficacy of pre-service PE teacher's toward teaching students with disabilities in GPE classes but before that it's important to briefly describe the importance of attitudes among PE teachers and to give short overview what has been done in the literature. Attitudes of teachers' are an important determinant of behavior in educational settings (Avradmidis \& Norwich, 2002), and ongoing discussion suggests that it is possible to predict behavior from intentions (Ajzen, 2005). Attitudes of physical education teachers' toward teaching students with disabilities in general physical education classes is seen as one of the most important barriers to the implementation of successful inclusion (O'Brien et al., 2009). There are numerous factors that can affect attitudes either, in positive way or negative.

Analyzing 38 studies pertaining to inclusion of students with disabilities in physical education published in professional journals both within and outside of the United States from 1995-2005, Block and Obrusnikova (2007), found that teachers' express negative attitudes toward teaching students with disabilities. They also report that those teachers' who do not feel competent have perception of inadequate training and lack of experience as well as knowledge to successfully include students with disabilities. In contrast to the findings of Block and Obrusnikova (2007), Martin and Kudlacek, (2010), conducted a study in which they describe the attitudes and determine predictors of intension in pre-service teachers in Australia toward inclusion students with physical disabilities in GPE classes. The authors found positive attitudes among Australian students toward teaching individuals in GPE classes with disabilities and no significant differences between year group or subject major.

Attitudes between genders can vary as well while the previous experiences in teaching students with disabilities and coursework in APE have positive influence. Hodge (2013) analyze the beliefs about inclusion and teaching students with disabilities of physical educator (PE) majors from Universities in North Carolina (NC) conducted descriptive survey situated in the theory of planned behavior (Ajzen, 2001). Demographic data of this survey used in this study included participants' gender, age, ethnicity or race, academic major, coursework in APE and special education, and experience teaching individuals with disabilities. Hodge (2013) reported different attitudes between female and male participants. Female revealed more willingness for additional preparation for teaching students with disabilities than male. Students who had prior teaching experience were more ready to accept teaching individuals with disabilities than those who didn't have; what actually support previous studies about positive influence on attitudes. Matriculation in introductory APE courses with practicum experiences creates favorable attitudes for teaching students with disabilities (Hodge \& Jansma, 1999). In support with those findings Hodge et al. (2009) found that those teachers' who had more experience and course work in working with students with disabilities favor inclusion more than those who didn't. The authors also revealed that classrooms with more students will lead to less inclusive than classrooms with less students.

Attitudes can be affected by the amount of academic preparation. Pedersen, Cooley and Hernandez (2014), did a survey with participants from two different Universities in Australia; investigating if Australian pre-service PE teachers' beliefs, attitudes and intensions about teaching students with disabilities was influenced by the amount of academic preparation they received during their PE pre-service teachers training. The authors found favorable dispositions toward teaching students with disabilities. However, the students from the Universities who received more pre-service training in teaching student with disabilities had more favorable beliefs, attitudes and intensions than the less-trained students.

This brief overview of pre-service PE teachers' attitudes toward teaching students with disabilities, undoubtedly give us an evidence of importance of it when we talk about the inclusion and students with disabilities. Prior experience in teaching students with disabilities, coursework in APE, workshops, professional development, curriculum, size of class and amount of academic preparation about teaching students with disabilities 
in GPE are one of the most effective factors for developing favorable attitudes in pre-service PE teachers'. Those factors will than lead to more positive results for the students, while on the other hand, unfavorable attitudes will lead to less positive results among students (Combs et al., 2010).

\section{Self-Efficacy Theory}

One of the most important element of Bandura's Social Cognitive Theory (SCT), is the concept of self-efficacy (Bandura, 1977). Selfefficacy is human characteristic which develops as life-long process. Many theories have tried to explain the developmental changes of different human capabilities. SCT favors a model of causation involving triadic reciprocal determinism where behavior, cognition and other personal factors as well as environmental influences all influence each other bidirectionally (Bandura, 1989). In order to realize their goals, to achieve success, people must have beliefs that they control everything that affect their lives; they can act with stronger motivation if they have such beliefs and their actions will be more effective. Perceived self-efficacy it's simply one's belief in his own skills, capabilities and actions used effectivel (Bandura, 1994).

According to Bandura (1997), self-efficacy influences one's functioning by three major ways: Cognitive - that involves knowledge, people who have higher perception of self-efficacy have wider and long-term observations; they challenge themselves and control their acting thinking about positive results only. Motivational - people can motivate themselves by making their beliefs of their capabilities and they put the goals, planning their own actions expecting positive consequences. Their motivation will be stronger as they believe that they can achieve their goals and perceived self-efficacy determines the goals, efforts and persistence and how resistant they are when troubles and failures come. Dispositions and emotions - how stressful and depressive people can feel in difficult and threatening life situations depends on how capable they are to solve problems with high efficacy, which influences emotional state. If someone has strong beliefs about self-efficacy, anxiety and stress will be lower, weaker and control under troubled thoughts will be better. On the other hand, if someone has low perceptions of self-efficacy, it can influence depression because the feelings of being incapable to prevent, to stop depressive thoughts can lead to disappointment in every sense of the word. Stronger feelings of self- efficacy is closely connected with better health conditions, higher achievements and better social integration (Bandura, 1997; Scholz, Doña, Sud, \& Schwarzer, 2002). On the end, if teachers' have high level of self-efficacy than, they will feel more able to perform specific task than those teachers' whose level of self-efficacy is lower.

\section{Self-Efficacy of Pre-Service PE teachers' toward teaching students with disabilities in GPE}

Self-efficacy is a situational specific form of self-confidence. So therefore, in regards to the field of PE we can say that, whether the pre-service PE teacher will be 'able' to organize and implement class including children with disabilities in or not; will be influenced by his/her level of self-efficacy. The theoretical framework of self-efficacy is more effective way to evaluate pre-service PE beliefs and predict their teaching strategies (Kozub \& Linert, 2003). Focus of this research will be to analyze the level of self-efficacy among students at the final year of Bachelor study of Sport and Physical Education from three Universities in Serbia.

Unfortunately, only few studies address this topic. First study which applied SE theory to PreService PE teachers' in regard to the inclusion of students with disabilities in GPE classes was the study of Hutzler, Zach and Gafni (2005). Their findings indicated that $\mathrm{SE}$ is positively related to attitudes toward including children with special needs in PE 153 students (95 females and 58 males ) participated in this study; examined with respects to the following variables and hypothesis: a) gender: females will have more positive attitudes towards inclusion; b) previous experience: students with previous experience will have more positive attitudes and higher self-efficacy; c) participation in an academic course pertaining to children with special needs: participants students will have higher SE and more positive attitudes; d) number of years in a teacher preparation institute: students with more years in college will have more positive attitudes and higher SE; and e) having instruction experience will have more positive attitudes. Two instruments were use for collecting data. The adapted version of ATIPE - The Attitudes towards including students with disabilities in PE lesson questionnaire (Shechtman, 1991) and SEIPE - The Self-efficacy in teaching PE under inclusive conditions (Hutzler, Zach, \& Gafni, 2005) T-test were used to compare between groups in dichotomous variables (gender, previous experience, participation in a course, 
participation in a youth movement). The impact of number of years in college on attitudes and SE was measured by means of one-way ANOVA with posthoc tests. Significant gender differences were found with more positive attitudes held by females. Students who had previous experience and those were attending the course $(\mathrm{p}<0.001)$, performed higher SE than those who didn't.

The last research that applied self-efficacy theory pre-service PE teachers toward teaching children with disabilities in GPE classes is the study of Taliaferro, Hammond and Wyant (2015). The authors investigated the effect of APE course with an associated practicum on pre-service physical educators self-efficacy beliefs toward the inclusion of individuals with specific disabilities (autism, intellectual disabilities, physical disabilities and visual impairment). Participants were 98 undergraduate Physical Education Teachers Education (PETE) majors at a large Midwestern Universities in the United States. All participants were enrolled in one of two 15-week APE courses.

\section{METHODS}

\section{Participants}

The collection of data is completed during the last month of the seventh semester among students at the final year of studying Sport and Physical Education (PE) of the three Universities in Serbia. Participants were 120 students (75 males and 45 females), all from the last year of study. An average age of male students among three Universities who were participating in this research was 22.85 years, while the average age of female students was 22.44 years. There were 23 students more who were in the third year of studying whose answers we didn't take into consideration. Research was based on the self-efficacy of students in the final year of studying Sport and PE at the three main Universities in Serbia toward teaching students with an intellectual disabilities (ID), physical disabilities (PD) or visual impairment (VI) in General Physical Education (GPE) program.

Inclusion criteria was that only students who were in the last year of studying sport and PE from three main Universities in Serbia (Novi Sad, Belgrade and Niš) could participate in this research. In order to ensure relatively equal number of students from each University we printed an equal numbers of questionnaires for each Faculty and forwarded them to professors in city of Novi Sad and Belgrade to conduct this research with their students. Implementation of the questionnaires at the Faculty of Sport and Physical Education Nis, was done personally. All participants completed the questionnaire voluntarily.

\section{Instrument}

Situational-specific Self-Efficacy and Physical Educators Scale (SE-PETE-D) was used for this study. The scale was used to measure the selfefficacy of students in the last year of studying Sport and PE from three Universities in Serbia toward teaching students with ID, PD or VI in GPE program. The SE-PETE-D was developed and validated by Block, Hutzler, Barak and Klavina (2013) in the English language. In order to conduct this scale with students from Serbia English version has been translated in Serbian. The technique of translation which was used is back-translation technique (Brislin, 1986) and requires four bilingual translators. First, two translators will translate the English version into the Serbian language separately. When they compare their translation, they forwarded the translated version to the other two bilingual persons who then retranslated the instrument back into English. Finally, the retranslated version was compared with the original version by one of the original version's authors for final approved.

The questionnaire begins with the directions of survey, general instructions, explanation of selfefficacy theory and an example for using the rating scale while answering an item. The survey has four parts.

The first part consists of the description of questions related to the accommodations of student with ID who is included in your GPE classes and is followed by 11 questions. The second part is focused on PD followed by 12 questions while the third part is focus on VI and is followed by 10 questions. The survey ends with the fourth part which consists of demographic questions such as age, sex, year in college, whether the students had GPE internship in a middle or high school, are they have any courses in APE, are they enrolled in undergraduate minor or concentration in APE, did their course of APE have a practicum, have they ever had experience with students who have any type of disability in physical education or community sports and have they ever had personal experience with people with disabilities within family, among friends or with someone in school. The competency scale for each question is from 1 (no confidence) to 5 (complete confidence). 


\section{Data Analysis}

Descriptive statistics (i.e. University, gender, number of participants, means, and standard deviation) was used to present characteristics of participants. Since the distribution of data in both Universities and genders were normal; t-test and Analysis of Variance (ANOVA) were used to answer our research questions. In order to determine the level of self-efficacy among students at the final year of studying Sport and PE from three main Universities in Serbia toward teaching students with disabilities in GPE classes and to determine students from which University will have the highest and which students will have the lowest level of self-efficacy toward teaching students with disabilities, One-Way ANOVA test was used. To find out if there were any differences between genders toward their competency to teach students with different types of disabilities, $\mathrm{t}$ test for independent sample was used while to give an answer on the following question: Toward which type of disability the level of self-efficacy among students will be highest and toward which type of disability will be lowest? T-test for paired samples was used.

\section{RESULTS}

TABLE 1 The level of self-efficacy among PE students from Serbia toward teaching children with disabilities in GPE classes

\begin{tabular}{|c|c|c|c|c|c|c|c|c|c|c|}
\hline \multirow{2}{*}{ Variable } & \multirow{2}{*}{ Gender } & \multicolumn{3}{|c|}{ Novi Sad } & \multicolumn{3}{|c|}{ Belgrade } & \multicolumn{3}{|l|}{ Niš } \\
\hline & & $\mathrm{N}$ & Mean & St.Dev. & $\mathrm{n}$ & Mean & St.Dev. & $\mathrm{n}$ & Mean & St.Dev. \\
\hline \multirow[t]{3}{*}{ ID-avg } & male & 18 & 3.48 & 0.35 & 32 & 3.50 & 0.51 & 25 & 3.75 & 0.47 \\
\hline & female & 27 & 3.21 & 0.56 & 12 & 3.95 & 0.54 & 6 & 4.17 & 0.56 \\
\hline & total & 45 & 3.32 & 0.50 & 44 & 3.63 & 0.55 & 31 & 3.82 & 0.51 \\
\hline \multirow[t]{3}{*}{ PD-avg } & male & 18 & 3.49 & 0.53 & 32 & 3.66 & 0.56 & 25 & 3.60 & 0.69 \\
\hline & female & 27 & 3.19 & 0.74 & 12 & 3.80 & 0.64 & 6 & 4.12 & 0.68 \\
\hline & total & 45 & 3.31 & 0.67 & 44 & 3.70 & 0.58 & 31 & 3.69 & 0.71 \\
\hline \multirow[t]{3}{*}{ VI-avg } & male & 18 & 3.48 & 0.49 & 32 & 3.47 & 0.70 & 25 & 3.47 & 0.59 \\
\hline & female & 27 & 3.11 & 0.82 & 12 & 3.62 & 0.93 & 6 & 4.13 & 0.77 \\
\hline & total & 45 & 3.25 & 0.72 & 44 & 3.51 & 0.76 & 31 & 3.58 & 0.67 \\
\hline \multirow[t]{3}{*}{ Overall-avg } & male & 18 & 3.48 & 0.38 & 32 & 3.55 & 0.49 & 25 & 3.61 & 0.51 \\
\hline & female & 27 & 3.17 & 0.61 & 12 & 3.80 & 0.61 & 6 & 4.14 & 0.62 \\
\hline & total & 45 & 3.30 & 0.54 & 44 & 3.62 & 0.53 & 31 & 3.70 & 0.57 \\
\hline
\end{tabular}

Legend: ID-avg - intellectual disability average; PD-avg - physical disability average; VI-avg - visual impairment average; overall-avg - overall score average 75 male participants and 45 female participants from all three Universities in Serbia, 18 male and 27 female participants in Novi Sad, 32 males and 12 females in Belgrade and 25 males and 6 females in Nis. According to information's from table 2 we can see what level of self-efficacy among students at final year of studying sport and physical education from three main Universities in Serbia toward teaching students with disabilities in GPE classes. Responses range between 3.11 (mean of female responses from the University of Novi Sad toward teaching students with VI) and 4.17 (mean responses of female responses from the University of Nis toward teaching students with ID). Results also show that students from Faculty of Sport and Physical Education, University of Niš, feel the most able to teach students with disabilities in GPE classes, overall mean score of the level of self-efficacy is 3.61 for males and 4.14 for females, while students from Faculty of Sport and Physical Education, University of Novi Sad, beliefs are less confident to teach students with disabilities in GPE classes in Serbia, overall mean score for those students is 3.48 for male participants and 3.17 for females. 
Results from the demographic questions show that from 120 participants how many participated in this study, $35.8 \%$ said that they didn't have internship in GPE during their study (Figure 1) while $81.7 \%$ answered that they didn't have any courses related to APE or APA during their study Only 10 students were enrolled in undergraduate or concentration in APE.

In order to see if there is any significant differences among students from all three Universities we were used one-way ANOVA (Table $2)$. Results from the table show that there is significant differences among students' level of self- efficacy from three Universities toward teaching students with ID $(F=8.76 ; p=0.001)$ and PD $(F=5.03$; $p=0.01$ ) in GPE classes in Serbia.

To determine differences among students between each University separately Post Hoc test analysis was used. Furthermore, using Fisher Least Significant Differences test (LSD) we found out that there is significant differences (Table 3 ) between the students level of self-efficacy of University of Novi Sad and University of Belgrade $(p=0.01 ; p=0.01)$, as well as between students level of self-efficacy of University of Novi Sad and University of Nis $(p=0.00 ; \quad p=0.01) \quad$ regarding ID and PD

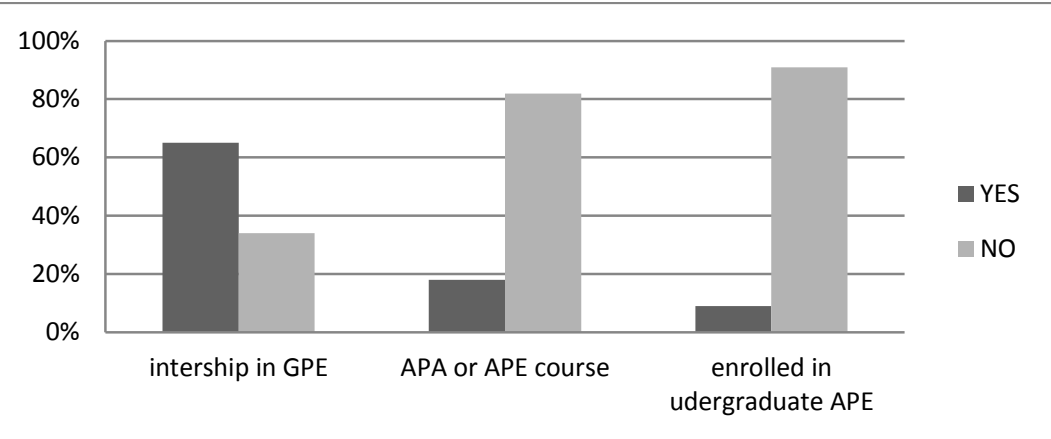

Figure 1 Percentage of PE students: a) who had internship in general physical education; b) who had experiences in adapted physical education or adapted physical activities course; c) who was enrolled in undergraduate or concentration in APE.

TABLE 2 One-Way ANOVA test shows significant differences among students' level of self-efficacy toward teaching children with disabilities in GPE classes

\begin{tabular}{|c|c|c|c|c|c|c|}
\hline Variable & University & $\mathrm{N}$ & Mean & Std. Deviation & $\mathrm{F}$ & $\mathrm{p}$ \\
\hline \multirow[t]{3}{*}{ ID_AVG } & Novi Sad & 45 & 3.32 & 0.50 & \multirow[t]{3}{*}{8.76} & \multirow[t]{3}{*}{$0.001 *$} \\
\hline & Belgrade & 44 & 3.63 & 0.55 & & \\
\hline & Niš & 31 & 3.82 & 0.51 & & \\
\hline \multirow[t]{3}{*}{ PD_AVG } & Novi Sad & 45 & 3.31 & 0.67 & \multirow[t]{3}{*}{5.03} & \multirow[t]{3}{*}{$0.01 *$} \\
\hline & Belgrade & 44 & 3.70 & 0.58 & & \\
\hline & Niš & 31 & 3.69 & 0.71 & & \\
\hline \multirow[t]{3}{*}{ VI_AVG } & Novi Sad & 45 & 3.25 & 0.72 & \multirow[t]{3}{*}{2.25} & \multirow[t]{3}{*}{0.11} \\
\hline & Belgrade & 44 & 3.51 & 0.76 & & \\
\hline & Niš & 31 & 3.58 & 0.67 & & \\
\hline
\end{tabular}

Legend: ID-avg - intellectual disability average; PD-avg - physical disability average; VI-avg - visual impairment average; overall-avg - overall score average, F-frequency, p-significant differences; $p<0.05^{*}$

which indicates that students at the final year of studying Sport and Physical Education from the University of Novi Sad have the lowest level of selfefficacy toward teaching students with ID and PD in
GPE classes in Serbia. To determine differences among students between each University separately Post Hoc test analysis was used. Furthermore, using Fisher Least Significant Differences test (LSD) we 
found out that there is significant differences (Table 3) between the students level of self-efficacy of University of Novi Sad and University of Belgrade $(p=0.01 ; p=0.01)$, as well as between students level of self-efficacy of University of Novi Sad and University of Niš $(p=0.00 ; p=0.01)$ regarding ID and
PD which indicates that students at the final year of studying Sport and Physical Education from the University of Novi Sad have the lowest level of selfefficacy toward teaching students with ID and PD in GPE classes in Serbia.

TABLE 3 Significant results of LSD post hoc test for ID, PD and Overall

\begin{tabular}{lll}
\hline ID-avg & Belgrade & Niš \\
\hline Novi Sad & $0.01^{*}$ & $0.00^{*}$ \\
Belgrade & & 0.13 \\
\hline PD-avg & Belgrade & Niš \\
\hline Novi Sad & $0.01^{*}$ & $0.01^{*}$ \\
Belgrade & & 0.97 \\
\hline Overall & Belgrade & Niš \\
\hline Novi Sad & $0.01^{*}$ & $0.00^{*}$ \\
Belgrade & & 0.52 \\
\hline
\end{tabular}

ID-avg - intellectual disability average; PD-avg - physical disability average; overall-avg - overall score average, significant differences; $p<0.05 *$

TABLE 4 Results of t-test for independent samples regarding gender differences in whole sample and significant of the University

\begin{tabular}{|c|c|c|c|c|c|}
\hline Whole sample & gender & $\mathrm{N}$ & Mean & SD & p \\
\hline \multirow[t]{2}{*}{ ID_AVG } & male & 75 & 3,58 &, 47 & 0.68 \\
\hline & female & 45 & 3,54 & ,68 & \\
\hline \multirow[t]{2}{*}{ PD_AVG } & male & 75 & 3,60 &, 59 & 0.32 \\
\hline & female & 45 & 3,47 &, 78 & \\
\hline \multirow[t]{2}{*}{ VI_AVG } & male & 75 & 3,47 & ,61 & 0.51 \\
\hline & female & 45 & 3,38 &, 91 & \\
\hline \multirow[t]{2}{*}{ OVERALL_AVG } & male & 75 & 3,55 &, 47 & 0.42 \\
\hline & female & 45 & 3,46 & ,71 & \\
\hline \multicolumn{6}{|l|}{ Belgrade } \\
\hline \multirow[t]{2}{*}{ ID_AVG } & male & 32 & 3,50 &, 51 & 0,01 * \\
\hline & female & 12 & 3,91 &, 54 & \\
\hline \multicolumn{6}{|l|}{ Niš } \\
\hline \multirow[t]{2}{*}{ VI_AVG } & male & 25 & 3,47 &, 59 & $0.03 *$ \\
\hline & female & 6 & 4,13 &, 77 & \\
\hline \multirow[t]{2}{*}{ OVERALL_AVG } & male & 25 & 3,61 &, 51 & $0.04 *$ \\
\hline & female & 6 & 4,14 &, 62 & \\
\hline
\end{tabular}

Legend: ID-avg - intellectual disability average; PD-avg - physical disability average; VI-avg - visual impairment average; overall - overall score average, F-frequency, p-significant differences; $p<0.05^{*}$ 
Differences between genders are tested by ttest for independent samples. Results show that there are significant differences between males and females in their level of self-efficacy at the University of Belgrade toward teaching students with ID (mean of female responses was 3.95 while mean of male responses was $3.50 ; p=0.01$ ) and between males and females level of self-efficacy at the University of Niš toward teaching students with VI (mean of female responses was 4.13 while mean of male responses was $3.47 ; p=0.03$ ). There are no significant differences found between whole simple differ by gender.

TABLE 5 Results of t-test for paired samples

\begin{tabular}{|c|c|c|c|c|}
\hline University & $\begin{array}{c}\text { Type of } \\
\text { disability }\end{array}$ & Mean & SD & $\mathrm{p}$ \\
\hline Belgrade & ID_AVG & 3,63 &, 55 & 0.34 \\
\hline \multirow[t]{5}{*}{$\mathrm{N}=44$} & PD_AVG & 3,70 &, 58 & \\
\hline & ID_AVG & 3,63 &, 55 & 0.26 \\
\hline & VI_AVG & 3,51 & ,76 & \\
\hline & PD_AVG & 3,70 &, 58 & $0.03 *$ \\
\hline & VI_AVG & 3,51 &, 76 & \\
\hline Nis & ID_AVG & 3,82 &, 51 & 0.11 \\
\hline \multirow[t]{5}{*}{$\mathrm{N}=31$} & PD_AVG & 3,69 &, 71 & \\
\hline & ID_AVG & 3,82 &, 51 & $0.02 *$ \\
\hline & VI_AVG & 3,58 & ,67 & \\
\hline & PD_AVG & 3,69 &, 71 & 0.31 \\
\hline & VI_AVG & 3,58 & ,67 & \\
\hline Total & ID_AVG & 3,56 &, 56 & 0.8 \\
\hline \multirow[t]{5}{*}{$\mathrm{N}=120$} & PD_AVG & 3,55 & ,67 & \\
\hline & ID_AVG & 3,56 &, 56 & $0.02 *$ \\
\hline & VI_AVG & 3,43 &, 73 & \\
\hline & PD_AVG & 3,55 & ,67 & $0.03 *$ \\
\hline & VI_AVG & 3,43 &, 73 & \\
\hline
\end{tabular}

T-test for paired samples (Table 5) was use to determine differences between the level of selfefficacy toward different types of disabilities. Significant differences show up among students at the Faculty of Sort and Physical Education, University of Belgrade between teaching students with PD and VI. Students from Belgrade feel more able to teach students with PD rather than students

with VI (PD-M=3.70, VI-M=3.51; $p=0.03$ ). Significant differences also show up among students at the Faculty of Sport and Physical
Education, University of Niš between teaching students with ID and VI. They feel more confident to teach students with ID than students with VI (ID-M=3.81, VI-M=3.58; $p=0.02$ ).

\section{DISCUSSION}

Results from the demographic questions show that from 120 participants, how many participated in this study, $35.8 \%$ said that they didn't have internship in GPE during their study 
while $81.7 \%$ answered that they didn't have any subject or courses related to APE or APA during their study. Only 10 students were enrolled in undergraduate or concentration in APE. Faculties in Serbia usually offer courses and subjects in APA and inclusion as optional or on higher degree as master program. Bc. study last four years and after students graduate, they are qualified to work as PE teachers in elementary and secondary-high school. Hence the need for management and education of cadres, the needs of initial training in inclusive PE not at the postgraduate program (master level) but started undergraduate program. Another problem arises in the form of poor attendance of optional subjects with topic in APA. Just a few students choose to enroll to this course.

Faculty of Sport and Physical Education, University of Belgrade, offer two optional subjects Sport for All and Sport for People with Disabilities. Sport for All as a subject expected from students to know the methods and models of organizing a system of social and professional organization in the area of recreation, to know connections among biological age, psychological development, social environment and the type of load on the connection between recreational interests and needs of certain categories of inhabitants. Knowledge of physical ability in recreation in certain categories of citizens, as well as models of implementation of recreational programs for students, employees, children, people with disabilities, pensioners, women. The second subject, Sport for people with disabilities aimed to approach the involvement of people with disabilities in sports activities. The main objective of the course is to develop students' positive attitude towards people with disabilities, explain the importance of sport and recreational activities for this population, and to offer specific recommendations for exercise and practical application. There is no other subject or course at the faculty to teach students and to support inclusion in GPE yet.

The scientists and lecturers at Faculty of Sport and Physical Education from Novi Sad have been interested in APE last few years. A several publications investigated attitudes of future and current PE teachers towards inclusive physical education, current situation and future prospects about inclusive PE in schools (Tubić \& Đorđić, 2012), the role of interdepartmental committees in inclusive physical education development (Đorđić \& Tubić, 2011) and need of initial training of PE teachers for inclusive teaching in region of ex Yugoslavia (Đorđić, 2012). Đorđić (2012) analysis of the currently existing programs at the faculties in the region (Serbia, Croatia, Slovenia, Bosnia and Herzegovina, Montenegro, FYR Macedonia) show that the most frequently APA is studied within the frame of optional subjects or to a limited extent - as part of other subjects, especially Kinesitherapy, as well newly Motor Control and Development. Notwithstanding, projects supporting inclusion in PE are launched by Faculty of Sport and Physical Education in Novi Sad, still Bc. program for future PE teachers does not offer subject or courses related to adapted physical education (APE) or inclusion in general physical education (GPE). Postgraduate program offer as well optional course in Adapted Physical Exercise, with accent on Paralympics sports

In spring 2013, when this survives were applied in Faculty of Sport an Physical Education in Niš, only two courses were in offer Adapted Physical Exercise as optional on Bologna Bc. program and open course in Adapted Aquatics for all interested colleges, students, PE teachers, as well for people and students with disabilities. The number of interest subject increase in 2014 to Bc. curriculum Sport for Persons with Disabilities, master program curriculum Holistic Approach to Adapted Physical Activity and Inclusion in Managed Physical Activity. Since 2005. to 2009. Faculty of Physical Culture (at that time), University of Niš has been in CEEPUS network for Adapted Physical Activity, which enable exchanges of students and professors, exchange of experiences and acquiring new, between partner faculties from Czech Republic, Croatia, Bulgaria, Slovakia, Slovenia, Poland. Furthermore, since 2007 till today four graduated students from this faculty won award full scholarship to attend European program Erasmus Mundus Master in Adapted Physical Activities for one or two years.

Piletic and Davis (2010) in paperwork a profile of the introduction to adapted physical 
education course within undergraduate physical education teacher education programs describe the profile, content, delivery mechanism, and application of teaching standards, National Association of Sport and Physical Education (NASPE) and Adapted Physical Education National Standards (APENS) in US. Student population was cross disciplined (i.e. teacher education, exercise science, athletic training) 136 faculty members who taught the Introduction to APE course representing 129 different colleges/universities from 41 states in US. Content areas identified as a major emphasis (5 or more hours of lecture) were Disabilities (72\%), Instructional and Motivational Strategies (70\%), Modifications (70\%), Physical fitness, Motor skills, and Motor development of students with disabilities (59\%), and Writing and Implementation of Individual Education Plans $(52 \%)$. Practicum experiences were included within $84 \%$ of the introductory courses. Experience has been favorable to attitudes of PE teacher candidates from those with limited or no experience (Block \& Rizzo, 1995; Hodge \& Jansma, 2000). Attitudes have been identified as a key variable to the success of a physical education teacher's inclusive practices within the classroom (Martin \& Kudlacek, 2010). Additionally, research indicates that pre-service teachers may form negative pre-judgments or opinions towards teaching students with disabilities without actually engaging in a handson experience (Hodge, Murata \& Kozub, 2002). Recently researches monitoring influence of coursework, practicum and disability camp program (Papaioannou., Evaggelinou, \& Block, 2014) gave a positive results.

Differences among students' level of self-efficacy among three Universities responses between ranges 3.11 (mean of female responses from the University of Novi Sad toward teaching students with VI) and 4.17 (mean responses of female responses from the University of Nis toward teaching students with ID). SE differences range from ID - Niš $M=3,82$ vs. Belgrade $M=3,63$ vs. Novi Sad $\mathrm{M}=3,32$, for PD - Beograd $\mathrm{M}=3,70$ vs. Niš $M=3,69$ vs. Novi Sad $M=3,31$; VI - Niš $M=3,58$ vs. Beograd $M=3,51$ vs. Novi Sad
$M=3,25$. The comparison study between Hungary and US (Strehli, Blok, Farkas \& Bognar, 2012) pointed out significantly higher US student's SE self-efficacy compared to Hungarian students in SE for questions specific to disability type: (ID Hungary $\mathrm{M}=3.38$, US $\mathrm{M}=3.77$; t-test $=3.60$ $\mathrm{p}=.001$ ), for (PD - Hungary $\mathrm{M}=3.42$, US $\mathrm{M}=4.04$; t-test=5.24 p=.00) and (VD - Hungary $\mathrm{M}=3.38$, US M=3.78; t-test=2.87 $\mathrm{p}=.01$ ). Comparing to our Universities US student's SE have higher mean score in all type of disabilities except to students of Universities of Nis (UN) in regards to ID (US $\mathrm{M}=3,77$; $\mathrm{UN} \mathrm{M}=3,82$ ), while comparing to Hungarian student's SE of students at UB and UN is higher in all parameters respectively.

Furthermore, results from this study have shown significant differences among students' level of self-efficacy from three Universities toward teaching students with ID $(F=8.76$; $p=0.00)$ and PD $(F=5.03 ; p=0.01)$ in GPE classes in Serbia. When determine differences among students between each University separately Post Hoc test analysis and Fisher Least Significant Differences test (LSD) have found significant differences between the students level of selfefficacy of University of Novi Sad and University of Belgrade $(p=0.01 ; p=0.01)$, as well as between students level of self-efficacy of University of Novi Sad and University of Nis $(p=0.00 ; p=0.01)$ regarding ID and PD which indicates that students at the final year of studying Sport and Physical Education from Novi Sad have the lowest level of self-efficacy toward teaching students with ID and PD in GPE classes in Serbia.

\section{Differences by gender}

Differences between genders are tested by t-test for independent samples. Results have shown significant differences between males and females level of self-efficacy at the University of Belgrade toward teaching students with ID (mean of female responses was 3.95 while mean of male responses was $3.50 ; p=0.01$ ) and between males and females level of self-efficacy at the University of Nis toward teaching students with VI (mean of female responses was 4.13 while mean of male responses was $3.47 ; p=0.03$ ), females had more positive attitudes than male students. The trend of more positive attitudes among the females is in 
accordance with previous research related to attitudes towards participation of children with special needs in physical education classes summarized elsewhere by Hutzler (2003). Compared to males, typically female PE majors express more favorable attitudes toward teaching individuals with disabilities (Folsom-Meek \& Rizzo, 2002). Important though after controlling for experience differences using an analysis of covariance statistical application, Hodge and Jansma (2000) found no significant differences between the attitudes of male and female PE majors.

Based on the Theory of Reasoned Action (Ajzen, 1991), the significant differences of self efficacy suggest females may have better acquired the norm of teaching under diverse conditions, incorporated in the inclusion approach. Numerous findings in the USA reported by Bain (1990) suggest that males are more conservative and authoritarian, and have a stronger orientation towards coaching rather than teaching. FolsomMeek \& Rizzo (2002), for example in a study of PE majors $(n=2,943)$ at 192 colleges and universities across the United States (US), affirmed main effects for (a) gender (favoring females), (b) academic major (favoring non-PE majors), and (c) hands-on experience (favoring experience teaching individuals with disabilities) in positively influencing participants' attitudes toward teaching students with disabilities. There are inconsistencies however in research findings from studies on the attitudes of female versus male PE majors toward teaching students with disabilities.

\section{Differences by type of disabilities}

The type of disability of children taught also appears to influence the attitudes of physical educators. T-test for paired samples has been used to determine differences between the level of selfefficacy toward different types of disabilities. Significant differences show up among students at the Faculty of Sport and Physical Education, University of Belgrade between teaching students with PD and VI. Students from Belgrade feel more able to teach students with PD rather than students with VI (PD-M=3.70, VI-M=3.51; $p=0.03$ ). Similar findings in favor of attitudes towards children with physical disabilities were reported in the German study by Schmidt-Götz, Doll-Tepper \& Lienert (1994). Significant differences also show up among students at the Faculty of Sport and Physical Education, University of Nis between teaching students with ID and VI. They feel more confident to teach students with ID than students with VI (ID$\mathrm{M}=3.81$, VI-M=3.58; $\quad p=0.02$ ). Considering attitude toward and self-efficacy teaching students with different type of disabilities students and teachers of PE from US and Europe typically had better attitudes towards teaching children with learning disorders compared to children with physical disabilities, sensory disabilities and mental retardation (Hodge \& Jansma, 2000; Hutzler, Zach \& Gafni, 2005).

\section{CONCLUSION}

Regardless of the inexperience of the students results are not surprising. The reason could be because they have no adequate subjects and courses within the program at faculty, because they are not familiar with how the organization and adaptation of physical education classes for children with disabilities is complex and requires much expertise that is gained in the courses. Faculties of Sport and Physical Education in Serbia regarding the subjects and courses related to adaptive physical education and inclusion should increase responsibility to prepare graduates capable for teaching children with disabilities, offering diverse curriculum regarding to adapted physical education.

\section{Perspective}

The example of good practice would be to establish the cooperation with schools and teachers, teaching students with special needs (for example: school for visual impaired students, hearing impairment, intellectual disabilities, schools that need help with inclusion) and to put student in process assisting in physical education or organization of games. Also, a project is needed as financial support for faculties to buy material and equipments for various sports and activities that include persons with disabilities (for 
example: wheelchair for basketball or tennis, sound ball for goal ball, boccia or monoski). It can be also opportunity for faculties and students to organized courses for children, schools and organizations that cannot afford or are not able organized alone. Yet for some activities are not necessary special conditions nor expensive equipment, but it takes only a little will and heart.

\section{REFERENCES}

Ajzen, I. (1991).The theory of planned behavior, Organizational Behavior and Human Decision Processes, 50, 179-211.

Ajzen. I. (2001). Nature and operation of attitudes. Annual Review of Psychology, 52, 27-58.

Ajzen, I. (2005). Attitudes, Personality and Behaviour (2nd ed.). Berkshire, England: Open University Press.

Aloia, G., Knutson, R., Minner, S. H., \& Von Seggern, M. (1980). Physical education teachers' initial perceptions of handicappedchildren. Mental Retardation, 18, 85-87.

Ammah, J. O., \& Hodge, S. R. (2005). Secondary physical education teachers' beliefs and practices in teaching students with severe disabilities: A descriptive analysis. The High School Journal, 89(2), 40-54.

Avramidis, E., \& Norwich, B. (2002). Teachers' attitudes towards integration/inclusion: a review of the literature. European Journal of Special Needs Education, 17(2), 129-147.

Bain, L. (1990) Physical education teacher education, in: W. R. Houston, M. Haberman \& J. Sikula (Eds), Handbook of research on teacher education (pp.758-781).New York, NY: McMillan.

Bandura, A. (1977). Self efficacy: toward a unifying theory of behavioral change, Psychological Review, 84, 191-215.

Bandura, A. (1989). Human agency in social cognitive theory. American Psychologist, Vol. 44(9), 1175-1184.

Bandura, A. (1994). Self-efficacy. In V.S. Ramachaudran (Ed.), Enciclopedia of human behavior (pp. 71-81). New York, NY: Academic Press.
Bandura, A. (1997) Self-efficacy: the exercise of control. New York, NY: Freeman).

Block, M. E. (2007). A teacher's guide to including students with disabilities in general physical education, $3^{\text {rd }}$ edition, Baltimore, MD: Brookes Publishing Company.

Block, M. E., Hutzler, Y., Barak, S., \& Klavina, A. (2013). Creation and validation of the selfefficacy instrument for physical education teacher education majors toward inclusion. Adapted Physical Education Quarterly, 30(2), 184-205.

Block, M. E., \& Obrusnikova, I. (2007). Inclusion in physical education: A review of the literature from 1995-2005. Adapted Physical Activity Quarterly, 24(2), 103-124.

Block, M. E., \& Rizzo, T. (1995). Attitudes and attributes of physical educators associated with teaching individuals with severe and profound disabilities. Journal of the Association for Persons with Severe Handicaps, 20(1), 80-87.

Brislin, R. W. (1986). The wording and translation of research instruments. In J. Lonner \& J. W. Berry (Eds.). Field methods in cross-cultural research, 137-164. Newbury, CA: Sage.

Combs, S., Elliot, S., \& Whipple, K. (2010). Elementary physical education teachers' attitudes towards the inclusion of children with special needs: A qualitative investigation. International Journal of Special Education. 25(1), 14-125.

Downing, J.E. (2002). Including students with severe and multiple disabilities in typical classrooms: Practical strategies for teachers $\left(2^{\text {nd }}\right.$ ed.). Baltimore, MD: Paul H. Brookes Publishing Co.

Đorđić, V. (2012). Initial training of PE teachers for inclusive teaching: Situation in the region. In B. Krsmanovic, T. Halasi \& M. Dolga (Eds.), Summary: $\quad X X \quad$ International Interdisciplinary Symposium: Ecology, Sport, Physical Activities and Health of Youth (pp. 6-7). Novi Sad: Novosadski Maraton.

Đorđić, V., Tubić, T., \& Protić - Gava, B. (2014). Attitudes of teachers in rural and urban schools on inclusive physical education. Sport Sciences and Health, 4 1, 33-40. 
Folsom-Meek, S, L., \& Rizzo, T. (2002) Validating the physical educators' attitude toward teaching individuals with disabilities: PEATID-III survey for future professionals, Adapted Physical Activity Quarterly, 19, 141-154.

Goodwin, D. L., \& Watkinson, E. J. (2000). Inclusive education form the perspective of students with physical disabilities. Adapted Physical Activity Quarterly, 17, 144-160.

Hardin, B. (2005). Preparing physical educators for inclusion: Practitioners perceptions 23 regarding teacher education. The Physical Educator. 62(1), 44-56.

Hodge, S., \& Elliott, G. (2013). Physical Education Majors' Judgment about Inclusion and Teaching Students with Disabilities. Journal of Education and Training Studies, 1(1), 151-157.

Hodge, S., Ammah, J. O. A., Casebolt, K. M., LaMaster, K., Hersman, B., Samalot-Rivera, A., \& SatogHod, T. (2009). A diversity of voices: Physical education teachers' beliefs about inclusion and teaching students with disabilities. International Journal of Disability, Development and Education, 56 (4), 401-419.

Hodge, S, R., \& Jansma, P. (1999). Effects of contact time and location of practicum experiences on attitudes of physical education majors. Adapted Physical Activity Quarterly, 16, 48-63.

Hodge, S. R., \& Jansma, P. (2000). Physical education majors' attitudes toward teaching students with disabilities, Teacher Education and Special Education, 23, 211-224.

Hodge, S. R., Murata, N. M., \& Kozub, F. M. (2002). Physical educators' judgements about inclusion: a new instrument for preservice teachers. Adapted Physical Activity Quarterly, 19(4): 435-452.

Hutzler, Y. (2003). Attitudes toward the participation of individuals with disabilities in physical activity: A review. Quest, 55, 347373.

Hutzler, Y., Zach, S., \& Gafni, O. (2005). Physical education students' attitudes and self-efficacy towards the participation of children with special needs in regular classes.
European Journal of Special Needs Education, 20(3), 309-327.

Konza, D. (2008). Inclusion of students with disabilities in new times: Responding to the challenge. In P. Kell, W. Vialle, D. Konza, \& G. Vogle, (Eds.) Learner and the learner: exploring learning for new times. University of Wollongong (pp. 39-64). Available from http://ro.uow.edu.au/edupapers/36/.

Kozub, F. M., \& Linert, C. (2003). Attitudes toward teaching children with disabilities: Review of literature and research paradigm. Adapted Physical Activity Quarterly, 20(4), 323-346.

Lieberman, L.J., Alisa, R.J., \& Nicole, L. (2004). The Impact of Inclusion in General Physical Education for All Students, Journal of Physical Education, Recreation \& Dance, 75(5), 37-41.

Macura-Milovanovic, S., Gera, I., \& Kovacevic, M. (2011). Priprema buducih ucitelja za inkluzivno obrazovanje u Srbiji: Trenutno stanje i potrebe. Zbornik instituta za pedagoska istrazivanja, 43(2), 208-222.

Martin, K., \& Kudlacek, M. (2010). Attitudes of pre-service teachers in an Australian university towards inclusion of students with physical disabilities in general physical education programs. European Journal of Adapted Physical Activity, 3(1), 30-48.

Meegan, S., \& MacPhail, A. (2006). Irish physical educators ${ }^{\text {ee }}$ attitude toward teaching students with special educational needs. European Physical Education Review, 12(1), 75-97.

Mrug, S., \& Wallander, L. J. (2002). Self Concept of Young People with Physical Disabilities: does integration play a role? International Journal of Disability, Development and Education. 49( 3), 267-274.

O’Brien, D., Kudlacek, M., \& Howe, D. (2009). A contemporary review of english literature on inclusion of students with disabilities in physical education: A european perspective. European Journal of Adapted Physical Activity, 2(1), 46-61.

Obrusnikova, I., Block, M.E., \& Válková, H. (2003). Impact of inclusion in GPE on students without disabilities. Adapted Physical Activity Quarterly, 20, 230-245. 
Pantic, N., Closs, A., \& Macura-Milovanovic, S. (2012). The rationale for a wider concept of Inclusive Education for teacher education: A case-study of Serbia' Prospects, vol 42. DOI: 10.1007/s11125-012-9219-9.

Papaioannou, C., Evaggelinou, C., \& Block, M.E. (2014). The effect of a disability camp program on attitudes towards the inclusion of children with disabilities in a summer sport and leisure activity camp. International Journal of Special Education. 29(1), 1-9.

Pedersen, S. J., Cooley, P. D., \& Hernandez, K. (2014). Are Australian pre-service physical education teachers prepared to teach inclusive physical education? Australian Journal of Teacher Education, 39(8), 53-62.

Piletic, C., \& Davis, R. (2010). A Profile of the introduction to adapted physical education course within undergraduate physical education teacher education programs. ICHPER - SD Journal of Research in Health, Physical Education, Recreation, Sport \& Dance. 5(2), 26-32.

Salisbury, C., Gallucci, C., Palombaro, M., \& Peck, C. (1995).Strategies that promote social relations among elementary students with and without severe disabilities in inclusive schools.Exceptional Children, 62, 125-137.

Shechtman, Z. (1991) Changing attitudes of teachers in regular education toward integrating the exceptional in regular settings: empirical findings and an intervention plan. Dapim, 13, 54-59.

Schmidt-Götz, E., Doll-Tepper, G., \& Lienert, C. (1994) Attitudes of university students and teachers towards integrating students with disabilities in regular physical education classes. Physical Education Review, 17, 4557.

Scholz, U., Doña, B. G.; Sud, S., \& Schwarzer, R. (2002). Is general self-efficacy a universal construct? Psychometric findings from 25 countries. European Journal of Psychological Assessment, 18 (3), 242-251.

Snell, M.E., \& Eichenr, S.J. (1989). Integration for students with profound disabilities. In F. Brown \& D.H. Lehr (Eds.), Persons with profound disabilities: Issues and practices (pp. 109-138). Baltimore,MD: Paul H.Brookes publishing Co.

Stainback, S., \& Stainback, W. (1990). Inclusive schooling. In W. Stainback \& S. Stainback (Eds.), Support networks for inclusive schooling (pp. 3-24). Baltimore,MD: Paul H. Brookes Publishing Co.

Strehli I., Block M. E., Farkas J., \& Bognár J. (2012): Hungarian v. US pre-service physical educators' self-efficacy towards including children with disabilities in general physical education. NAFAPA, Birmingham, Alabama, October 11-13 (10).

Taliaferro, A. R., Hammond, L., \& Wyant, K. (2015). Preservice physical educators' selfefficacy beliefs toward inclusion: the impact of coursework and practicum. Adapted Physical Activity Quarterly, 32 (1), 49-67.

Tubić, T. \& Đorđić, V. (2012). Inclusive physical education in Vojvodina: the current situation and future prospects. Facta Universitatiss: Physical Education and Sport 10 (4), 319 327.

U.S. Government Accountability Office. (2010). Students with disabilities: More information and guidance could improve opportunities in physical education and athletics. (publication no. GAO-10-519).

United Nation (2006, December 6).Convention on the Rights of Persons with Disabilities. Final report of the Ad Hoc Committee on a Comprehensive and Integral International Convention on the Protection and Promotion of the Rights and Dignity of Persons with Disabilities, pp.1-33. Retrived from http://www.un.org/disabilities/convention/con ventionfull.shtml 